\title{
Urbanization and Its Impacts to Food Systems and Environmental Sustainability in Urban Space: Evidence from Urban Agriculture Livelihoods in Dar es Salaam, Tanzania
}

\author{
Wakuru Magigi \\ Moshi University College of Cooperative and Business Studies (A Constituent College of Sokoine University of Agriculture), Moshi, \\ Tanzania. \\ Email: magigi2000@yahoo.com \\ Received January $26^{\text {th }}, 2013$; revised February $28^{\text {th }}, 2013$; accepted April $1^{\text {st }}, 2013$ \\ Copyright (C) 2013 Wakuru Magigi. This is an open access article distributed under the Creative Commons Attribution License, \\ which permits unrestricted use, distribution, and reproduction in any medium, provided the original work is properly cited.
}

\begin{abstract}
Urbanisation is the key factor underpinning and catalysing changes in food systems, environmental quality, climate change and agriculture livelihoods in the overall urban ecosystem setting and its sustainability. The paper explores Dar es Salaam, a rapidly expanding city in Sub-Saharan Africa, and shows that urban agriculture provides urban ecosystem services and contributes to environmental sustainability. The interconnections of environmental justice, urban ecosystem services and climate change and variability found eminent feature that influence land governance, productivity and aesthetic value of the city. The study reaffirms the pivotal role urban agriculture which plays to enhance community health services and access to resources, with important implications on urban environmental sustainability and redistributive spatial land use planning policies and practices. The process of urbanisation, forms of urban agriculture and government strategies for enhanced urban food systems in the city economy have been highlighted. Equally, the process triggers the transformation of settlements from rural in character to modernity with an augmented land use conflicts. The results suggests that with increasing population, a clear spatial land use planning and management strategy is required to over- come the challenges and enhanced food systems and urban environmental sustainability in rapidly urbanizing cities like Dar es Salaam in Sub-Saharan Africa.
\end{abstract}

Keywords: Urbanization; Food Systems; Environmental Sustainability; Urban Space; Urban Agriculture; Livelihoods

\section{Introduction}

Urbanisation is the key factor underpinning and catalysing changes in land use, land transactions, increased rural-urban immigration and the overall urban agriculture land use in Dar es Salaam city. Unregulated urban agriculture implementation in urban and periurban land was found predominantly expanding in an unorganised manner in the city. Other factors include a reluctance of local and central government planning institutions to include the sector in land use plans for improved urban ecosystems interconnections with environmental conservation needs. The emerging urban agricultural land use pattern, by and large, indicates a mismatch with the widely cherished planning norms and standards and land market ${ }^{1}$.

\footnotetext{
${ }^{1}$ The land market was observed to influence land allocations and resident choices and is therefore an important factor in urban agriculture integration in and use planning practise for improved system.
}

Urban land use planning instruments such as zoning and density distribution and principles including equitable provision of basic services in urban land development are important ingredients for integrating urban agriculture in land use planning processes for improved urban ecosystems and food security.

The urbanisation process is accompanied with expansion of the city boundary, which engulfs periurban settlements. The process of expansion of the city boundaries is resulting in periurban settlements coming within the city's "zone of influence". This is increasing interaction of residents including smallholder farmers' access to the city economy, in terms of capital outsourcing from relatives and friends. Similarly, it helps the provision of labour and exchange of goods and services. This is one fact of the villages, from rural in character to periurban char- 
acter where conflicts in resource use becomes common. Likely, influence capital earnings which encourage home ownership through housing construction, where friends and relatives can inhibit when they arrive in the city for social obligations. Changing demography and particularly the changing age structure of the population, a high rate of urbanization, and a faster rate of population growth in relation to economic growth are major drivers of environmental change in Africa, with significant impacts on the natural resource base.This indicates the rationale of understanding the rural-urban symbiotic relations existing between the city and its hinterlands for sustaining livelihoods of the people and urban environment.

The symbiotic relations existing in nature observed to be economically and ecologically viable in terms of investment attractions including housing development, greening the city and opening up of social services. Principally, urban expansion lowers the amount of land potential for periurban agriculture in the city growth processes. The reduction of land for this sector appears to intensify poverty of smallholder farmers who depend on it as a livelihood strategy and increased environmental degradation. This suggests the need for urban planning institutions, after land declaration to establish a clear development conditions to safeguard urban agriculture forms which play a great part to ensure city greening, ecological conservations and food systems [1]. Food system in the context refers to process of households to have a substantial amount of food which include low cost in its production sphere throughout the year. Each year, as the population increases in the city with climate change impacts on crop production, food prices and the amount of natural resources, which is going to sustain this population, to improve the quality of lives and to eliminate poverty remain finite and therefore increasing the challenge of sustainable development achievements.

\section{Urban Planning and Land Declaration Need}

Population growth presents a major challenge because of the patterns of production and consumption that shape the world, as well as the problems of pervasive poverty. In adapting to this challenge urban land use planning need to be accommodative. This among others means the process of land declaration and zoning in urban land use planning system needs to be transparent and involve different actors with interest in land property development. The involvement of actors in land declaration and subsequently, decision making, preparation, implementation and monitoring ensures urban environmental sustainability. Otherwise, the non-involvement of these actors in planning processes lead to difficulties in institutionalising, coordinating and controlling urban agriculture prac- tice, effective resource utilization and misuse as well as difficulties in ensuring monitoring and evaluation of land use plans once implemented.

Conflict arising from landholders, fragmented types of cadastral survey prohibitive costs and increased housing densification are some features of ineffective land use planning. In addition, presence of land use conflicts and housing density results in decreased food production and they affect urban food systems. Increase price of various food types is an apparent feature in the city which affects the city poor and shifting to the periurban is the only alternative remain for the poor for survival in African cities. This is affecting residents' nutrition levels and subsequently labours productivity within the settlement and the city within environmental justice measure. Other factor enhancing the shift includes changes of the land market dynamics and prohibitive raise of life costs.

It is imperative to note that, the [2] shows that the $21^{\text {st }}$ Century is the century of the city, although a significant portion of humanity's impact on the global environment originates in urban areas. It continues showing that there are also opportunities to mitigate and adapt to global environmental change through urban planning processes. Half of the world's population already lives in urban areas and by the Middle of this century, most regions of the developing World will be predominantly urban. In supporting this, [3] estimates that today $33 \%$ of Africa's population lives in cities and by 2050 this will be $60 \%$. The report adds that Globally 800 million people are engageing in urban agriculture producing $15-20$ percent of all food. More people noticed are employed in processing, marketing and transporting. These arguments unravel the complexities of these relationship is a demand towards enhancing food systems and urban environmental sustainability in cities of Africa [4].

\section{Methods and Materials}

The study analyses the urban agriculture practise Goba, Chang'ombe "A" and Ubungo Darajani in Dar es Salaam City. Various forms of urban agriculture including vegetable production are analysed with special emphasis on understanding the questions of food security, urban poverty, environmental conservation and urbanization consequences in urban development processes. A total of 450 stakeholders were interviewed during this study.

The selection of the case studies was guided by various factors including a long and outstanding settlement development history, rapidly urbanizing settlements in terms of housing, social demographic changes and presence of agricultural activities. Both preliminary field data collection, desk search and on spot observation were methods deployed in data collection. Key informant in- 
terviews were carried out in the selected cases so as to establish the historical evolution of agriculture activities, food supply, markets, resource use, prices, land use planning practices, challenges, planning institutions roles and linkages to climate change, environmental conservation and urban ecosystems Data collected were analyzed using Statistical Package for Social Science (SPSS) and Map info Software. Throughout the analysis, data were differentiated regarding member's perceptions, activities, institutions arrangement and their roles and linkages, nature of activities, potentiality and negative impacts of agricultural activities for improved livelihoods of the residents in the study settlements and urban ecosystems environments.

\section{Results and Discussion}

Debate on sustainable human settlements spins on understanding and facilitation process of involving various planning institutions in reducing health burden, chemical and physical hazards, achieve high quality urban environment, increase city productivity and Foreign exchange earnings in the urban land management system and governance. It should also strive to achieve sustainable consumption, ensure food security and minimizes transfer of environmental burdens in urban development and ecological systems. Urbanization is central to global environmental change among other factors that is necessary to be an integral part in understanding urban sustainability, urban ecosystems and towards transition towards sustainability.

\subsection{Forms and Locations of Urban Agriculture in the Study Settlements}

Different forms and locations of urban agriculture exist in Dar es Salaam city. The urban agriculture provides income, nutrition and often a safety-net function to the poorest sectors of society and therefore enhances urban food systems, access to resources and social services within environmental justice perspectives. $65 \%$ of the farmers in both settlements studies reported using their farm product for subsistence while the rest used it for income earning and for giving to their relatives and friends. The selling takes place in the producer's home, and city markets including Kariakoo, Tandale, Temeke sterio, Makumbusho. The distance to market areas limits access of smallholder farmers to selling their perishable vegetable products to the retailers. These retailers buy from smallholder farming premises and sell both in the streets and in the big markets within the city. The long distance traveled by these retailers fetching vegetables from the farming premises to the market in the city is one of the voices of smallholder farmers. This reduces their profits, as they have to balance the cost of buying and selling. This indicates the need for improving the transport facilities in periurban areas to ensure the accessibility to consumers including to market places and enhance food system flows to residents. This also appears meeting the [5] explicitly recommends that; A paradigm shift in design and urban planning is needed that aims at reducing the Distance for transportation food by encouraging local food production, where feasible, within city boundaries and especially in immediate surroundings.

In addition, opening new markets in periurban settlements helps in reducing traveling distance and also in reducing congestion in the city during daytime when vehicle traffic jams to the city center increases. As such, urban agriculture is an important vehicle for poverty reduction in Dar es Salaam and other cities in Sub-Saharan Africa. However, the forms of urban agriculture practiced in the city are documented in Table 1.

Exposing urban agriculture to the public the knowledge, risks and way for sustaining the activity in relation to resource management is important. Respondents involving in floriculture and tree seedling contribute much to city environmental conservation and recreation. For example, floriculture and other canopy trees provide areas for resting and aesthetic value of the settlements studies. The problem among others includes lack of designated areas for ornamental tree, floriculture and seedlings in the city, which calls for more intervention in planning

Table 1. Farming systems common to urban areas in Dar es Salaam.

\begin{tabular}{|c|c|c|}
\hline Farming System & Product & Location and Markets \\
\hline Aquaculture & Fish and Seafood, vegetables, fodder & Fish ponds, river streams, sewerage and wetland: Within the city \\
\hline Horticultural & Vegetables, fruits, compost & $\begin{array}{l}\text { Home lots, parks, right-of-ways, wetlands, railway lines and undeveloped } \\
\text { and unfinished plots and houses }\end{array}$ \\
\hline Ornamental & Flowers, Tree & right-of-ways, Home lots \\
\hline Animal Husbandry & Milk and Eggs, Meats, Manure, Skin and hides & $\begin{array}{l}\text { Zero grazing, right-of-ways, steep and gentle slopes, open spaces, urban } \\
\text { fringe areas }\end{array}$ \\
\hline Poultry Keeping & Egs, Meats, Manure, income & Zero grazing in home lots \\
\hline Agri-forestry & Fuel, fruits and nuts, compost, building materials & $\begin{array}{l}\text { Home sites, steep and gentle slopes, wetlands, forests parks, urban forest } \\
\text { zones }\end{array}$ \\
\hline
\end{tabular}


and design for enhancing environmental conservation, social services such as recreation and income levels of actors involving in the sector. The use of road strip for cultivation is common and is expanding smallholder farmers' vulnerability to risks of eviction by the city council. In addition, the further the smallholder farmer's proximity in the city centre the more vulnerable they become compared to the periurban farmers. The former, accompanied with city harassment and fear of eviction, which proved to destruct the urban environment and create a nuisance.

\subsection{Urban Agriculture Requirement in the City and Interconnection with Environmental Change and Urban Ecosystem}

Urban agriculture as a land use function requires land, water, labour, inputs (seeds, fertilizers etc). The abundant and adequacy of these resources are limited in urban areas and therefore pressure on it and to climate change rehabilitation and adoptability becomes apparent feature. Farming systems adopted by city residents has a adverse impact of urban environmental and health of the residents. For example, crop rotation and mixed farming adopted by smallholder farmers in the three study settlements help increase their productivity and at the same time conserve land. In case of Goba settlements, it has been noted that local leaders already established socially regulated norms of not clearing bushes along the river sources to conserve the soil. The leaders argue that vegetable and other annual crop farming exposes the soil after bush clearing. Thus, the enhanced deforestation resulted in soil and climate changes. One landholder in Goba settlement remarked:

“...in the 1990's we experienced cold and pleasing air in our settlement throughout the year, today weather has changed and it is too hot almost throughout the year. I think this is caused by bush clearing for residential and urban farming land use in our settlement."

The statement shows bush clearing for farming has resulted in changes of the micro-climate. This reinforces the need for environmental conservation when urban agriculture strategies are to be accommodated in the city setting. Equally, it is the author's view that such a statement may only show a subjective perception or respondent. In addition, in both the study settlements, crop rotation of amaranth farming is popular. The practise involves land preparation, planting, weeding and harvesting processes. The majority of respondents reported to produce vegetables crops, which suffer from fewer diseases (Goba 90\%; Mabibo-72\% and Chang'ombe "A"$68 \%)$.

In both settlements environmental risks were associ- ated with poor management of inorganic wastes, the use of wastewater and the use of pesticides. The use of wastewater by some smallholder farmers and retailers before selling causes consumers to fear the health aspects associated with urban farming. How hygienically safe can this be? These sellers of green vegetables (mchicha) are washing their wares in the heavily polluted waters of the Mabibo River-Kibangu in Dar es Salaam. The water from this river is used in different sections of vegetable growing, especially during germination and in three weeks before harvesting. $87 \%$ of smallholder farmers show that even though are using this water, they used to leave using the water to one week before harvesting. One can wonder if the water in these rivers is polluted and to what extent? And if polluted, the time the smallholder farmers left without using the water as a preparation for harvest, does it have any health impacts? This shows training for smallholder farmers involved in farming product especially vegetables crops, as well more intervention on the raised question to clear fears voiced by consumers in the city for improved urban environmental justice. This means when people are trained will have equal awareness and see their potential in their involvement of all people regardless of race, color, sex, national origin, or income with respect to the development, implementation and enforcement of environmental laws, regulations, and policies in regard to urban agriculture implementation and legislative framework applications

\subsection{Problems Affecting Urban Agriculture in the City}

Urban agriculture faces a wide range of constraints in its production sphere. These include pest attacks, adverse weather conditions and timely access to inputs such as seeds and pesticides. Others include use of the suggested polluted river water for irrigation and land subdivision for residential premises. These are causing decline in the quantity, quality and safety of vegetables expected by consumers. Apart from that limited extension services to smallholder farmers to educate them on sustainable urban farming are hardly provided and therefore increases disease vulnerability. Respondents from Goba-64\%, Ubungo Darajani- $70 \%$ and Chang'ombe " $A$ "- $67 \%$ confess inadequate of extension services in their areas. Extension services provision to smallholder farmers, ensure information flows, marketing and dissemination of new innovation are factors appeared that could enhance their productivity in the city. Urban Agriculture livelihood found that the large proportion of producers rely on buyers for market information

Besides, fear of eviction of the respondents by the government is common and in one way affects crop culti- 
vation in periurban areas such as Goba, which was declared as ripe for urban development. Problems of insecure to access land as an input plagues urban smallholder farmers almost everywhere in the city where different forms of urban agriculture practice discussed are conducted. Specific land problems arise because by-laws and regulations prohibit food production of certain types especially livestock rearing, but sometimes crops. Smallholder farmers are often pushed out of their land and it is taken for residential and commercial purposes. This affects the smallholder farmers who want to engage in improving their farm lots for social and economic benefits but lacks funds for improving their plots in urban areas as the study settlements shows.

\subsection{Environmental and Climate Change Impacts Associated with Urban Agriculture}

It was difficult for smallholder farmer respondents in the three cases to give a proper answer on how much sucks or harvests they get in quantity per month. This was due to a lack of record keeping that could enable them to understand how much he or she harvested per day, month or per year. The knowledge observed from smallholder farmers are calculations done through number of ridges they have and the cost of seeds purchased during germination period. $52 \%$ of smallholder farmers even forget how many lots or terraces they have harvested per season. The rest seem to remember number of lots in their heads with no record keeping. Similarly the question of labour and time spent in farming are not counted as they do not regard the activity to be a permanent employment and livelihood strategy. This shows that more training is needed in record keeping and costing inputs used in farming for the betterment of farmers.

The use of wastewater for vegetable farming in the study settlements is a common practise. Both domestic and industrial wastes are flowing in river channels, which are in turn used for urban vegetable production. According to [6], in countries where poor sanitation and hygiene conditions exist and untreated waste water and excreta are widely used in agriculture, intestinal worms pose the most frequently encountered health risk (Table 2).

Decision makers including planners have negative altitude toward urban agriculture practise. Most of planners are questioning about the health aspects resulting from the use of waste water which seems to be heavily polluted from rivers for farming and washing products. Likewise, urban agriculture has been blamed for increasing malaria cases in cities, which according to recent studies is questionable ${ }^{2}$. Wastewater treatment is important ${ }^{3}$, but may be difficult since even domestic wastes water and sanitation systems in the settlements are directed to these rivers, which increases more health risks of consumers. Thus, upgrading of these settlements and training of smallholder farmers can be important for improving their livelihood including urban food system in the urban setting increases the fairness of decisions to achieve environmental justice objectives.

Climate changes, water availability and perishable nature of amaranth vegetable products cause it to be seasonal activity in the city. This affects the sells and income level and adds pressure on water use during the dry season. The organisation of the sector in a proper land area becomes important where infrastructure facilities can be provided, and monitored and profits to the majority ensured. It is through land use planning that this can be achieved and land can be properly allocated to add value to agricultural land.

\subsection{Environmental Justice Effects on Policy within the Communities}

According to land development policy, the fragile and hazardous land needs to be zoned for conservation. This includes being conserved by planting trees to prevent erosion and land degradation. The reality observed is that these areas have been encroached upon by smallholder farmers and people developing their settlements. Inadequate policy and legal enforcement to guide these haz-

Table 2. Summary of health risks associated with the use of wastewater for irrigation.

\begin{tabular}{|c|c|c|c|}
\hline \multirow{2}{*}{ Group exposed } & \multicolumn{3}{|c|}{ Health threats } \\
\hline & Helminths & Bacteria/viruses & Protozoa \\
\hline Consumers & $\begin{array}{l}\text { Significant risks of helminth } \\
\text { infection for both adults and } \\
\text { children with untreated waste water }\end{array}$ & $\begin{array}{l}\text { Cholera, typhoid and shigellosis outbreaks reported } \\
\text { from use of untreated wastewater; seropositive } \\
\text { responses for Helicobacter pylori (untreated); increase } \\
\text { in non-specific diarrhoea when water quality exceed } \\
10 \text { exponent } 4 \text { thermotolerant coliforms per } 100 \mathrm{ml}\end{array}$ & $\begin{array}{l}\text { Evidence of parastic protozoa found } \\
\text { on wastewater-irrigated vegetable } \\
\text { surfaces, but no direct evidence of } \\
\text { disease transmission }\end{array}$ \\
\hline
\end{tabular}

Source: [6].

${ }^{2}$ Study conducted by [7] in the city of Dar es Salaam shows that high number of Malaria parasites are not associated with urban agriculture, instead poor drainage and sanitation system are the cause.

${ }^{3}$ See also [8]. 
ardous lands as well as controlling housing development in these areas seems to be a major problem for smallholder farmers. Particularly, problems are resulting from continuous land subdivision for construction purposes, which limits urban agriculture practise. Smallholder farmer respondents (i.e. $72 \%$ in Goba, $78 \%$ in Ubungo Darajani and $84 \%$ in Chang'ombe "A") show that they were not aware of the use of such land and restrictions behind it. Likewise, no land use plans showing the use of that land are put in place at local level. Apart from that neither local leaders nor local authority staff informed them on such use if any. This indicates inadequate communication and information flows in coordinating and controlling land development in the city.

Farmers are handling the manure and composite on their farms without awareness of the health risks associated with faecal contaminations. Using manure and composite wastes can affect human health through contaminations, and therefore increases residents' vulnerability to diseases. This is caused by the handling of manure on their farm lots as the study shows.

Although the quantity of food produced by city farming does not match up to that outside the city, its impact is quite considerable when looking at its social aspects, especially in terms of its employment, nutritional values and food security for the families. It is the authors' view that although the national and municipal policy makers and urban managers do not acknowledge this important role, we need to consider it in modern urban planning and design decisions. This can help to minimises several challenges posed to urban farming including understanding if urban land is either not available or not accessible; and when available, it is suitable or not suitable for farming in designated sites. The market managers show that one aspect among others that the urban planners and other stakeholders doubt is the existence of vegetable wastes in market areas and in residential premises. They confirm that the agriculture wastes are beneficial. The wastes are easily decomposed and are used in existing farms and therefore employ people and at the same add nutrients to soils used for farming within the city.

According to [9], urban agriculture is classified in Use class $\mathrm{P}$ which according to this Act requires special treatment in its sitting. Using the same Ordinance, section 78 empowers the Minister responsible for planning and for putting in place regulation to protect land development. This shows that the [9] and use class $\mathrm{P}$ have been redefined to enable their integration in policy implementation. However, though this shows recognition of urban agriculture in policies that implement legislative framework, it does not provide prominence that would allow useful implementation. For example, it has been difficult to know which land type is suitable and how it can be inte- grated in other land uses including residential areas in both urban and periurban settlements. Due to the importance and contribution of urban agriculture as seen in this context, location, type and scale determinants are preferred for proper coordination and control. Similarly, use of local leaders including deployment of Subward and Ten cell leaders in coordinating and controlling such development are vital to ensure sustainable use of land and enhancing urban ecological systems.

\subsection{Challenges Influencing Urban Agriculture Setting and Production in Connections with Climate Change, Environment and Urban Ecosystem Services}

\subsubsection{Contractual Relations Are Very Important to Build Trust}

In the three settlements explored, people access land for urban agriculture and other land use function through buying, inheritance and granted right of occupancy. The study showed that $78 \%$ of the respondents interviewed are not aware of official procedure requirements for getting land for urban agriculture. This is because they have little contact with government agencies and the English language is used for these policy and legal documents. For example, planning regulations, standards and administrative procedures are published in English while the majority of landholders and tenants cannot read or speak English (92\%) in all settlements explored. Only $8 \%$ of smallholder farmer respondents could speak and write English. In this regard use of the Swahili language to communicate these procedures would be preferable.

The granted right of occupancy has built confidence in the smallholder farmers involving in plot farming in the study settlements. These farmers understand that they are secure in terms of not being evicted by the local authority, or must receive high compensation value in case of eviction or compulsory land acquisition for public interests. These farmers are aware of the by-laws guiding urban agriculture particularly on restricting high raised crop farming such as maize in their plots in Ubungo Darajani and Chang'ombe "A". This has increased vegetable, mushroom and floriculture farming for improved income and social well-being.

In the three settlements examined, smallholder farmers were not well organised. The smallholder farmers understand the potential of their farming activity for improving their social well-being, but they have not united to form an organization. This is also augmented by different tenure status, reasons for farming and plot size. For example, some farmers depend on only farming for their household subsistence while others for petty business. Some farmers observed are secured in terms of land ownership while others are not. Similarly, other smallholder farmers 
use inplot farming while others are offplot including a fragile land. Forming an organization can enhance their rights to use the land in whatever tenure to be granted and to negotiate on land user rights for increasing their productivity. Correspondingly, this will help to present their feelings and perceptions in improving the sector to politicians including Ward Councilors who are the policy makers and representative in their area. The link of smallholder farmers with this political leadership is minimal, which enhances marginalisation of smallholder farmers. The organization of smallholder farmers would help fight for better prices for their by-products and other matters in the production sphere, and would improve urban land governance for city development.

\subsubsection{Inadequate and Inaccessibility to Information and Transparent}

Access to information, communication and credit facilities are resources that are important for improving smallholder farmer welfare. The study indicates that smallholder farmers are experiencing inadequate access to land, information, delivery systems and rights to get involved in land use planning. This limits the improvement and understanding of their rights available opportunities, and interaction with planning institutions. This results resulting in difficulties in decisions undertaken at different levels, which affect urban agriculture livelihoods, needs for food storage system and maintaining a range of urban food supply sources, which are important elements is sustaining lives of poor resourced persons and achieving environmental justice.

The availability of credit for urban farming including amaranth farming activities is one factor that can pull the respondents out of poverty and improve urban land governance. $93.8 \%$ of respondents in the study settlements had no access to credit. Only $2.2 \%$ of respondents in Goba reported having received credit of up to 400 USD. In Chang'ombe " $\mathrm{A}$ " and Ubungo Darajani settlements the figure is only $4 \%$. This indicted the need for putting in place and strengthening credit scheme access that can help to improve the lives of smallholder farmers. Likely, insecurity of land tenure as collateral enhances this. This character seems common in other African cities including Nairobi and Uganda as reported by [10].

The system of access to land includes both statutory and customary tenure occur for a number of reasons. In some cases, the original settlements were developed under traditional or customary tenure systems on land which was at the time outside urban administrative boundaries, but was later absorbed within them as the urban areas expanded. At such times, various statutory tenure categories, such as formal granted right of occupancy have been introduced, to which later construction had to conform.
The cases of Chang'ombe "A" and Goba show this. Alternatively, early developments may have changed their tenure status as legislation changed, or regularisation programmes enabled previously informal settlements to become legal as in the case of Ubungo Darajani.

In addition, $6 \%$ of smallholder farmer respondents owning land in the three study settlements were observed to have short-term titles of 2 - 21 years offered by Local authority. This limits smallholder farmers' access to financial institutions for credit. For instance one landholder said:

"...I have got a title deed, but I have been constrained by the short term nature of title given (i.e. 2 years). Credit institutions refuse to provide a loan arguing that the title has low betterment value."

This quote shows that even though the residents are aspiring to get titles as a tool for asset betterment, the lease is too short and unattractive to credit institutions. Therefore, there is a need to consider granting a longterm title i.e. 33, 66 and 99 years leasehold to attract financial betterment to smallholder farmers who want to legalise their land towards poverty for community development. Providing a range of tenure options could be the most effective means of enabling the urban poor to improve their living conditions and livelihood opportunities and therefore improve urban land governance. In addition, existence of both customary and granted right of occupancy by having both urban and village administration working together need more intervention including deregistration of the later.

\section{Increasing housing density}

Demand for land for housing and other urban investment including industrial construction is increasing in the city and the settlement in particular. Informal land transaction and parcelling, land subdivision in mixed residential areas including the study settlements has caused the decrease of agriculture land and encroachment upon what would be public leisure spaces. All this results from increasing investment in the city and homeownership needs of urbanities, where each needs to have a decent house in the city. This calls for urgent action of the local authorities and other planning authorities to collaborate and control the increasing density resulting from informal land transactions taking place in the study settlements and the city as a whole. If this is unchecked, the future urban environment can be degraded and therefore endanger the fate of the incoming generation.

\section{Public open space utilisation}

In the planned parts of Goba, Ubungo Darajani and Chang'ombe " $A$ " where urban land use plans exist, urban agriculture is dominant and it is practiced in plots and offplots. In parts of these settlements, informal settling exists which seems to encroach upon unplanned open 
spaces, which are zoned as conservation lands or hazardous lands. Development control of the open spaces is hardly done and therefore allows soil and environmental degradation, and increasing land use conflicts. Checking these impacts to avoid future settlement degradation is rational for sustainable use of urban land.

\subsection{Planning Institutions Linkages}

A notable problem is that the municipal council's operations in the city are inconsistent with the principles stated in the policy and legal documents which require integration of urban agriculture in urban planning system. Equally, the [11] seem not to be mentioning who will be responsible for coordinating this sector. The policy and legal statement is therefore observed to be too abstract to anchor the institutional body that will be accountable. For example, interviews with different institutions show the following responsibilities and the way they perceive urban agriculture (Table 3).

Table 3 indicates that urban agriculture has been integrated in policy and legal settings as one of the urban land uses. But one wonders whether it belongs to Ministry of Local Government or Ministry responsible for Lands. These Ministries as planning institutions are responsible for land use preparation and policy, regulation and order making and approve the same. Principally, they are the one who can help coordinate and control farming by connecting with other line Ministries. One wonders why they are hesitant. This is the policy enforcement gap, which is important to address in order to promote urban agricul- ture. This suggests the need for the government to form a separate body within the Ministry and for the Municipality to deal with the issue of urban agriculture and link with the Ministry responsible for Agriculture and Livestock, Health and Water. The officials in the Ministries mentioned are hesitant on dealing with the issue, as it will add more administration cost.

In supporting the foregoing, the author argues that if the government wishes to adopt such arrangement, conditions for developing such land are important rather than exposing the free land market to take place. These conditions can entail ways of building construction and orientation, in plot activities including allowed forms of urban agriculture and others planning principles discussed. Agriculture land is part of settlement upgrading and livelihood strategy for the poor, which in practises are excluded by not having its designated land.

\section{Planning standards}

The formal land use planning standards and regulations, for example those being used in new formal settlement development, would generally not be appropriate for upgrading many informal settlements. These will impose severe payment burdens on residents, or the building of a particular type of housing which is difficult to afford by smallholder farmers. These farmers would find it very difficult to remain in a settlement upgraded according to conventional regulations. Besides, they fear that they cannot keep up with payments of land property tax and do not have the means to begin building an approved permanent house because of their unsustainable

Table 3. Planning institutions responses in coordinating urban agriculture.

\begin{tabular}{|c|c|c|c|c|c|}
\hline \multirow{2}{*}{ Central government } & \multicolumn{2}{|c|}{ Respondents } & \multicolumn{2}{|c|}{ Responses } & \multirow{2}{*}{ Remarks } \\
\hline & Male & Female & Yes & No & \\
\hline $\begin{array}{l}\text { Ministry responsible for lands and } \\
\text { human settlement development }\end{array}$ & 3 & 2 & $\mathrm{~V}$ & & $\begin{array}{l}\text { It is a form of land use in urban areas but hardly incorporated in planning } \\
\text { schemes due to legal restriction. But argues the Ministry responsible for } \\
\text { agriculture should be responsible }\end{array}$ \\
\hline Ministry responsible for health & 1 & - & & $\mathrm{X}$ & $\begin{array}{l}\text { Have no legal mandate to coordinate urban agriculture, but affects the urbanities } \\
\text { and argued is the cause of cholera and cause of malaria diseases }\end{array}$ \\
\hline $\begin{array}{l}\text { Ministry responsible for } \\
\text { livestock and agriculture }\end{array}$ & 1 & 1 & & $\mathrm{X}$ & $\begin{array}{l}\text { The official says they don't deal with urban farming. Only deal with rural urban } \\
\text { agriculture improvement as the urban context remains with Ministry responsible } \\
\text { for land }\end{array}$ \\
\hline $\begin{array}{l}\text { Ministry responsible for } \\
\text { water and energy }\end{array}$ & 1 & - & & $\mathrm{X}$ & Have no legal mandate to coordinate urban agriculture \\
\hline Ministry responsible for tourism & 1 & - & & $\mathrm{X}$ & $\begin{array}{l}\text { They confess its great potential for greening the city but it is the role of the } \\
\text { Ministry responsible for lands, local government and agriculture and not theirs }\end{array}$ \\
\hline $\begin{array}{l}\text { Ministry responsible for } \\
\text { local government }\end{array}$ & 1 & 1 & & $\mathrm{X}$ & $\begin{array}{l}\text { Argues urban agriculture gives meager profit to urban development and therefore } \\
\text { even the reforms may change its to belong to cooperative department and not as } \\
\text { such the way it looks }\end{array}$ \\
\hline President office of environment & 1 & & & $\mathrm{X}$ & $\begin{array}{l}\text { Argue to deal with urban farming when it brings environmental nuisance } \\
\text { otherwise they are less concern }\end{array}$ \\
\hline $\begin{array}{l}\text { Ministry for planning } \\
\text { and privatization }\end{array}$ & - & 1 & & $\mathrm{X}$ & $\begin{array}{l}\text { Looks urban area as area for investment of other profitable land use rather than } \\
\text { urban agriculture }\end{array}$ \\
\hline
\end{tabular}


income levels. This is affecting their living standards and livelihood opportunities in the urban areas and shifting to periurban land is common.

Planning standards and regulations interact closely with those for the design and construction of buildings, the provision of infrastructure and access to formal credit and plot size needs. Official standards on plot size are often based on arbitrary assumptions regarding individual family needs, rather than the costs or impact on density levels and urban land market intricate. Given the commercialisation of urban land markets that have accelerated during the last two decades, low densities plots seem to be resulting from large plots subdivisions. Allocating of smaller plots for individual household occupation particularly after plan approval was a strategy adopted.

\subsection{Infrastructure}

Dar es Salaam city water demand is influenced by pressure on its use and increasing population. The major water sources include Ruvu chini and Juu plants, Mtoni plants and the availability of deep and shallow water grounds in residential neighbourhoods. Water consumption per capita per day is 187 litres in the city. The breakdown of the water system, power interruptions and the poor state of the water system pipes are among critical problems facing the sector. Increased pressure on water use for industry and domestic needs results from population increase in the city affects the settlement environment. This results from both the limited sources of water and from climate change, which reduces water levels especially during the summer season. The expanding pressure on water use demands due to increasing population, limits the utility agency to formalise water use for urban agriculture. This restriction has not been adhered to by residents and illegal water connection is common in the case studies, which reduces the amount of water reaching to other parts of the city.

Lack of sanitation facilities including drainage, sewerage system and waste collection points in the three settlements have led to increased dumping of wastes including domestic, industrial, constructional and agricultural in rivers and in open spaces. This is caused by poor land use planning, inadequate policy and legal enforcement and poor awareness of urbanities on managing urban land as the study settlements shows. This has degraded the quality of the settlements in terms of increasing air, water and land pollution. Solid waste heaps and domestic water drains towards river lines are common.

\subsection{The Impact of Urbanisation}

Urbanisation is the key factor underpinning and catalysing changes in land use, land transactions, increased ru- ral-urban immigration and the overall urban agriculture land use in Dar es Salaam. It was observed that conflict arising from landholders, fragmented types of cadastral survey prohibitive costs and increased housing densification in both Chang'ombe " $\mathrm{A}$ " and Goba are the key features of ineffective land use planning within urbanisation processes. In addition, presence of land use conflicts and housing density may result in decreased food production. This is affecting residents' nutrition levels and subsequently labours productivity within the settlement and the city as a whole.

The health risks observed in the study settlements are those related to the use of wastewater resulting in excreta-related infectious diseases. In countries where poor sanitation and hygiene conditions exist and untreated waste water and excreta are widely used in agriculture, intestinal worms pose the most frequently encountered health risk [6]. Other excreta-related pathogens may also pose health risks, as indicated by high rates of diarrhoea, other infectious diseases, such as typhoid and cholera, and incidence rates of infection with parasitic protozoa and viruses. Thus, precautions are needed once agriculture practise is institutionalised in urban land development setting. For balancing smallholder farmers livelihoods while maintaining the city environment, health and economic returns of urban agriculture sector, training, partnership and involvement of actors in decision making is crucial. Thus, technical assistance is needed.

\subsection{Urban Agriculture: A Livelihood Strategy for Food Security and Poverty Reduction in Environmental Justice Context}

Different forms of urban agriculture persist in the City of Dar es Salaam. These forms of urban agriculture are providing nutritional food, employment, recreation, leisure and are greening the city. Urban agriculture contributes to poverty reduction and sustainable use of land.

Important factors influencing these forms of urban agriculture and therefore the urban environment sustainability include scarcity of land for farming, unstable crop prices, inadequate market for agriculture produce, poor packaging and poor record keeping, inadequate capital and long travel distance to the market. Other factors include absence of technology in wastewater treatment for irrigation and no clear designated areas for farming. These influencing factors create fear to smallholder farmers of involving in intensive production. Similarly, harassment from the local authorities is a common occurrence. This affects fresh food production and consumption and lowers income levels.

A desire to increase income and to supplement family consumption, nutritional value, income generation, employment alternatives and sign of prestige/hobby were in 
both settlements mentioned as motivation for actors' involvement in urban agriculture activities. This finding indicates the same as provided by [12]. 78\% of smallholder farmers involving in this activity are poor (i.e. live under 1 USD per day). Likewise, people with high economic integrity involve in livestock keeping and poultry husbandry. The former are the disadvantaged group in which less labour is required, while the later requires intensive care, labour payment and treatment, which for the poor is difficult to afford. Urban agriculture tends to supplement incomes of unemployed or under-employed men and women. For example, $68 \%$ of respondents i.e. smallholder farmers are involving in other social economic activities in their settlements to supplement the produce. The hot climate, the seasonality of the activity depending on rainfall and water from river streams seems to affect the production in the three study settlements.

\section{Conclusions}

\subsection{Legal and Policy Environment}

The agriculture policy environment in Tanzania is earmarked by a common dichotomy between urban and rural development administration. It leaves little scope for acknowledging the specific characteristics and needs of agriculture implementation in urban areas. Agricultural policies and programmes are primarily designed for rural areas, and are therefore not always compatible with the needs of urban agriculture. To bridge this gap, there are opportunities for linking activities and programmes in respect to land development including land use planning and National development programmes. For example, conducting workshops with smallholder farmers, linking with researchers, extension officers and policy makers having the capacity to affect agriculture is crucial. This therefore calls for involvement of different stakeholders and policy enforcement to effect urban development programmes as supported in legal and policy documents in the. This helps to create awareness among different stakeholders and therefore meets the interests of smallholder farmers and other land developers.

Urban planning professionals in practise use a traditional master plan approach stipulated under [8] in urban land use planning processes, which seems to be rigid and inflexible to changed circumstances in urban areas. Principally, the Act restricts urban agriculture. Despite of good-intentions in policy and legislations reforms intentions to ensure the community's involvement in land use planning, there still exists a vacuum regarding its operation at the grass-root level. For example, under the land regularization scheme as per [13], the power to determine whether or not to declare the regularization scheme and its implementation falls under the Minister for lands. The
Minister is also empowered to delegate functions to the Commissioner for Lands for the scheme execution. However, the substantive involvement of private sectors, and popular sector institutions to initiate and implement seems not to be emphasised in regularization process. Thus, in one way the Act, places smallholder farmers and their local authorities including village council who may want to formalise their land in a difficult position to directly and promptly intervene in an area, which has to be upgraded through land regularisation. The situation points out the need to decentralise land regularisation (i.e. land use planning) powers from central to local government, and to give the local community the power to initiate, implement and monitor land use planning outputs. With this respect, local authority and central government may wish to facilitate in terms of expertise, resources and plan endorsement as well as in implementation and monitoring modalities. This calls for a private public partnership in improving urban land governance.

\subsection{Social Capital Ties, Linkages and Community Assets}

Collaboration is about linkages and ensuring that all stakeholders perceive themselves as part of one group and not as outsiders facing "the others". Inadequate linkages and flow of information between smallholder farmers, the Local Authority, and the Ministry responsible for Local Government who endorse and approve policies and by-laws, and who may have a real functional mandate in coordinating and controlling urban agriculture livelihoods is common. Likewise, Ward Councillors who are political representatives of landholders including smallholder farmers are hardly visiting smallholder farmers to understand their problems. It was noted that even the Ward Councillors' decisions in practise are based on personal vested interest rather than technical and smallholder farmers' needs. Politics were also observed in decision making to interfere in spatial land use planning, land allocation and delivery systems in the study settlements, the city and the country as a whole. One smallholder farmer in Chang'ombe " $\mathrm{A}$ " remarked:

"...if the person is noted to belong to the opposing party, even if he presents the issue and that issue looks genuine for settlement development the issue is hardly taken into account."

The statement principally shows that policy making process is influenced by politics in land use planning. Similarly, smallholder farmers view the government (both central and local) as neglecting them as their needs are not taken into account. This discourages smallholder farmers from considering farming seriously as employment rather than as a temporary activity. No one wants to address this issue in public. This is creating an unfriendly 
environment between the two particularly when you consider food insecurity, employment and urban poverty in the development processes. Thus, linking politicians, government and private institutions through public/private partnership in land use development is rational in the case study areas and in the city as a whole for improving urban land governance in spatial land use planning processes.

Some investments have so far been made in the three study settlements. These include multi-million Tanzanian shillings worth of vertical and horizontal residential building construction. Others include agricultural production, commercial activities and other micro-economic activeties. The available investments are however still too few to foster rapid economic development of the areas and much has to be done to attract investments in these settlements. Urban agriculture forms formidable investments. In connection to agriculture production where at least every household uses agriculture products each day, land availability and management is important in maintaining this investment. Land as a community asset therefore provides potential livelihoods enabling residents living in the case study settlement and the city. A main finding was the weakness of extension services and marketing alternatives for smallholder farmers. This suggests a need for urgent design of new market areas in periurban zones of the city of Dar es Salaam to serve the urban poor. To avoid institutional conflicts over land use, deregistration of village land after declaration is vital in the city of Dar es Salaam for enhancing this community asset.

\subsection{Involvement}

The concept of community involvement in planning for sustainable ecological conservation is highly insisted upon in country urban planning and land management policy, programmes and legal documents. The changing of urban planning approaches from master plan and structure plan (i.e. unconventional approaches) to more inclusion of actors (i.e. conventional approaches) is one of the strategy to ensure involvement. The later includes land regularisation, which earmarks urban planning transition approaches towards sustainability through actors' involvement. The case study shows that the involvement of landholders including smallholder farmers in land use planning is critical in integrating urban agriculture in urban planning processes. Likewise, the case shows lack of review of the 1978 Dar es Salaam Master Plan has led to increased unorganised urban farming in the city. The review may be important for improving land and including urban agriculture through negotiations with actors and experts in the stages involved in land use planning practise.

\subsection{Financial Mobilisation}

Financial mobilisation for implementing land use plans forms a remarkable need for involving the local community in their settlements to upgrade and plan their neighbourhoods. The Ubungo Darajani case shows the power of local community resource mobilisation in improving urban land governance through involvement in land regularisation processes. The case of Goba landholders contributed funds to find lawyers when the government was implementing the land use plans without involving them. One smallholder farmer remarked:

"...we contributed funds meriting TSh. 300,000/= (i.e $240 \mathrm{U}$ ) to fetch the lawyer to assist in interpreting the land Law towards understanding what is our right and what belongs to the government. It was in this base where we understood our land rights and our right in involvement in land use plan making, making alternative plans and rejecting plans."

The statement indicates how different actors including the Lawyers and Ardhi university by then UCLAS as consultants help enable landholders to fight for their land rights in land use planning processes. The two examples show the willingness of landholders in their settlement towards improving their settlements. This shows the power of local communities when they are facing the same felt problems. The government may consider this readiness to improve the urban settlements and include urban agriculture within urban plans where possible to exploit this potential.

\subsection{Conclusions}

The paper contributes different issues and associated factors towards improving urban land governance through urban agriculture integration in spatial land use planning practice. Urban agriculture implementation continues to face challenges. Among the challenges demonstrated in this chapter we pinpoint the mindset of planners, urban managers and decision makers who do not see and value it the way the smallholder farmers and researchers do. The social subsistence of urban farmers and the economic contribution to income including employment are important. Contributions to nutrition, environmental conservation are also benefits. Planners, urban managers and decision makers think that urban agriculture is less valuable and makes a smaller contribution than rural agriculture. It is the authors' view that small contributions of urban agriculture to the poor sector of the society matters a lot as in future may result in crime if no proper production systems, forms and scale are less considered in urban planning. Thus, mainstreaming the sector in a proper framework in urban planning and management for apt city growth and development is rational. Likewise, ex- 
clusion of urban agriculture land use plans and inadequate water infrastructure provision, fear of health impacts, weak institutional coordination and legal enforcement are other challenges. Besides decision making, inadequate access to resources including information, communication, funds and lands are other constraining factors.

Power for policy making, initiation, declaration, acquisition, control and land use change for spatial land use planning belongs to the central government in most developing countries including Tanzania. Strong facts are needed to convince the government to address and promote urban agriculture. Its financial returns, health aspects, and potential to green the city are facts that could convince the government to make urban agriculture priority. For example, the country is implementing its strategy for poverty reduction of 2005; urban agriculture is not included in this important development vision document. The author is not of the view that community needs should overstate the country policy and legal setting, but defining critical roles of each actor, conduct monitoring, empowering local community to determine their development path and linking the legal setting to the reality is important. This helps break through the theory and practice gap and meet the community needs where the policy and legislation can change. The Policy and Acts are there to change under real challenges in the development process. It is only through addressing the issue that affects the local community and putting in place its importance in national development, that it can be listened to and taken into account rationally. Otherwise, subjective decision making will likely occur. To achieve this takes time and dedication from planners and other stakeholders. This suggests that in Dar es Salaam, where population is expected to expand, a clear spatial land use planning and management strategy is required to overcome these challenges. However, rejecting any systematic role of economics of urban agriculture livelihoods growth, especially in cases of urbanization process in developing countries is inevitable as poverty persist in African cities. The results suggests that, where population is expected to expand, a clear spatial land use planning and management strategy is required to overcome these challenges towards reducing negative externalities for enhanced food systems and urban environmental sustainability in Dar es Salaam and other Sub-Saharan Africa Cities of the same context.

\section{Acknowledgements}

I would like to thank the community members of the study areas in Dar es Salaam (Goba, Chang'ombe, Ubungo and Mbezi settlements) involved in providing information during this research implementation. I thank DAAD of Germany for providing funds for this research implementation.

\section{REFERENCES}

[1] W. J. Kombe, "Land Use Planning Challenges in PeriUrban Areas in Tanzania," Spring Research Series, Vol. 29, Dortmund, 2002.

[2] United Nations Human Settlements Development Report, New York, 2009.

[3] Worldwatch Institute, "The Renewables 2010 Global Status Report Provides an Integrated Perspective on the Global Renewable Energy Situation," Washington DC, 2010 .

[4] L. J. A. Mougeot, "Urban Agriculture, Definition, Presence, Potentials and Risks," In B. Niko, Eds., Feldafing, German Foundation for International Development (DSE), 2000 .

[5] Un High Level Task Force on the Global Food Crisis, New York, 2008.

[6] World Health Organization (WHO), "Guidelines for the Safe Use of Wastewater, Excreta and Grey Water: Policy and Regulation Aspects, Vol. 1,"WHO France, 2006.

[7] S. Dongus, D. Nyika, K. Kannady, D. Mtasiwa, H. Mshinda, U. Fillinger, A. W. Drescher, M. Tanner, M. C Castro and G. F. Killeen, "Participatory Mapping of Target Areas to Enable Operational Larval Source Management to Supress Malaria Vector Mosquito in Dar es Salaam, Tanzania," International Journal of Health Geographics, Vol. 6, No. 1, 2007, p. 37. http://dx.doi.org/10.1186/1476-072X-6-37

[8] A. Inocensio, H. Sally and D. J. Merrey, "Innovative Approaches to Agriculture Water Use for Improving Food Security in Sub-Saharan Africa," Sri-Lanka, IWA, Colombo, 2003.

[9] United Republic of Tanzania, "Town and Country Planning Ordinance-Cap 378 Revised in 1961," Government Printer, Dar es Salaam, 1956.

[10] V. Kreibich and W. H. A. Olima, "Urban Land Management in Africa," Spring Research Series, Vol. 40, Dortmund, 2002.

[11] United Republic of Tanzania, "Land Use Planning Act," Government Printer, Dar es Salaam, 2006.

[12] R. Nugent, "The Impact of Urban Agriculture on the Householdss and Local Economics," 2000.

[13] United Republic of Tanzania, "Land Act," Government Printer, Dar es Salaam, 1999. 